\title{
2D-POROSITY OF CRUSTED SILTY SOILS: INDICATORS OF SOIL QUALITY IN SEMIARID RANGELANDS?
}

\section{Miralles-Mellado}

Estación Experimental de Zonas

Aridas CSIC

04120-Almería

Spain

Y. Cantón

Dep. of Soil Science

University of Almería

04120-Almería

Spain

A. Solé-Benet*

Estación Experimental de Zonas

Aridas CSIC

04120-Almería

Spain

\section{ABSTRACT.}

Little is known about the morphological characteristics of pores in soil crusts. The objective was to characterize the 2D-porosity (amount, shape, size and area of pores) of soil crusts to ascertain their potential as indicators of soil quality for natural crusted soils. 2D-porosity was described in thin sections and measured by image analysis of polished resin-impregnated soil blocks. Physical soil crust and incipient biological soil crusts appear to be the lowest-quality soils in terms of number of pores (average of 131 to $133 \mathrm{~cm}^{-1}$ ) and area occupied by pores or meso-macroporosity (3.5 to $4.2 \%$ ). Their most abundant pore types were small unconnected rounded pores. Soil crust infiltration coefficients (65-75\% annual) were among the lowest and their high erosion rates ( 81 to $204 \mathrm{~g} \mathrm{~m}^{-2} \mathrm{y}^{-1}$ ) and low infiltrability (47 to 61\%) were not only due to their lower total porosity, but also to their pore shapes and sizes. Biological soil crusts appear on higher-quality soil, where the higher the organic $\mathrm{C}$ content, the more evolved the soil crust is (with lichens and cyanobacteria). Such soil crusts have better developed poresystems with specific meso- and macropore morphologies, e.g., large, interconnected elongated and irregular pores. Biological soil crusts dominated by lichens have the largest meso-macroporosity (up to $23.65 \%$ ) due to the predominance of elongated pores. In many cases, infiltration is low (46 to 57\%) because the biological crusts are somewhat detached from the soil underneath, but the armouring effect decreases erosion rates ( 7 to $23 \mathrm{~g} \mathrm{~m}^{-2} \mathrm{y}^{-1}$ ). Soil crust pore numbers, size and shape were useful indicators of soil quality.

Abbreviations: PSC, physical soil crust; BSC, biological soil crust; IBC, incipient biological soil crust; LC, lichen crust; CVS, crusted vegetated surface; ROI, region of interest. 


\section{INTRODUCTION}

Physical and biological soil crusts (PSC and BSC, respectively) constitute the main types of soil cover in most arid and semiarid areas worldwide. Although they are an almost negligible portion of the soil profile, they play a significant role in ecosystems (Belnap et al., 2001), as they control vertical and horizontal fluxes of nutrients, water, gases and heat to and from the soil (Beymer and Klopatek, 1991; Belnap 1995; Belnap and Gillette 1998). PSCs are transient soil-surface layers (ranging in thickness from less than $1 \mathrm{~mm}$ to a few $\mathrm{cm}$ ) that are structurally different from the material immediately beneath them. BSCs are a complex mosaic of cyanobacteria, green algae, lichens, mosses, microfungi, and other bacteria (Belnap et al., 2001).

Considering that arid and semiarid regions cover about $40 \%$ of the Earth's land surface (Reynolds et al., 2007), the mentioned effects on the ecosystems where soil surface crusting appears may play a crucial role in soil quality (NRCS, 1996). At present, soil quality is defined not only in terms of soil production capacity, but also in terms of stability or resilience to environmental perturbation (Hartemink, 1998; Miralles et al., 2009). However, despite the fact that soil quality has been subjected to extensive research (Singh and Tripathy, 1992; Jurgensen et al., 1996; Sahani and Behera, 2001, and references therein), most studies are carried out at humid sites and very few in arid or semiarid zones (Miralles, 2007; Miralles et al., 2009). In such zones, physical and biological crusts are especially fragile to environmental constraints (microtopographical features leading to abrupt changes in slope, orientation and exposure of soils, unpredictable rainfall, etc.) and certain human actions that lead to severe erosion and degradation (Belnap 1995; Miralles, 2007), and in general, alter soil quality. In this sense, the assessment of soil quality in crusted soils is of particular importance to forecasting the resilience of the whole ecosystem. In natural ecosystems soil crusting is a very dynamic suite of processes which can influence soil quality, but unfortunately little is known about them.

It is well known that evaluation of soil surface structure provides valuable information about physical soil quality (Dexter, 2004). Therefore, soil crusts, as a type of soil surface, should also provide such information. Some authors have evaluated soil structure by considering the complete soil profile (Dexter, 2004; Ball et al., 2007; Miralles, 2007). However, Cavalieri et al. (2008) noted that the soil structure of the surface layer can be even more crucial to soil 
physical quality than other soil properties, such as texture or bulk density, and the soil just below the surface layer might also play an important role. These authors showed that the surface layers were less porous and had less macroporosity and higher soil bulk density than underlying layers. However, the saturated hydraulic conductivity and intrinsic air permeability were higher at the surface than in deeper layers (Bhattacharyya et al., 2006, Azooz and Arshad, 1996). Hence, the best conditions for gas and water exchange are found in the surface layers, where soil has a higher organic carbon content and biological activity and better structure with well-connected pores. The importance of the surface layer is especially critical in crusted soils as crusts regulate all the processes in the underlying soil. As in natural ecosystems, not all soil surface crusts behave the same in pedological and hydrological terms. It would be attractive to consider some specific properties of soil crusts and the soil immediately underneath it, e.g., porosity and pore characteristics, as indicators of soil quality.

Among the above considerations, it is also well known that soil sealing and crusting causes strong changes in the pore system of the top layer (Panini et al., 1997; Assouline and Mualem, 2000), and that transient surface seals and physical crusts strongly reduce the size and continuity of macropores (Pagliai, 1987; Panini, 1997). However, very few papers on BSCs report that such crusts have larger pore volumes (Malam-Issa, 2009; Verecchia et al., 1995). When studied by $\mathrm{Hg}$ intrusion porosimetry, $\mathrm{Hg}$ is observed to enter gradually and continuously through pores in contrast to adjacent uncrusted soil or soil with very low BSC cover (Malam-Issa, 2009). The porosity of both the crust and the soil underneath it modulates water transit through the soil, depending on the connectivity and the size of pores. Belnap (2006) showed the need to study soil crust structure and porosity to better understand their role in infiltration and erosion. However, transient surface seals and crusts on agricultural soils have been studied much more (Assouline, 2004; Lee et al., 2008; among many others) than soil crusts in natural areas.

According to Greenland (1977), 0.5 to $50-\mu \mathrm{m}$ pores (storage pores) are a water reservoir for plants and microorganisms, and 50 to $500-\mu \mathrm{m}$ pores (transmission pores) are important in soil-water-plant relationships and in maintaining good soil structure conditions. Pores $>500 \mu \mathrm{m}$ (fissures) are particularly useful for water infiltration and drainage in fine-textured soil (Panini et al., 1997). Luxmoore (1981) classifies pore sizes of less than $10 \mu \mathrm{m}$ as micropores, from 10 to $1000 \mu \mathrm{m}$ as mesopores and above $1000 \mu \mathrm{m}$ as macropores with functions similar to those above. However, these pore functions are related not only to their 
size but also to their shape and connectivity, as round unconnected pores are less effective in transmitting water than connected, irregular and elongated pores (Panini et al., 1997; Valentin, 1991; Fox et al., 2004). In this sense, the detailed quantification of the size, shape and connectivity of pores could allow precise soil water movement modelling (Bouma, 1981; Germann and Beven, 1981; Douglas, 1986; Pagliai et al., 2004) and would thus provide useful information about soil infiltration processes (Valentin and Bresson, 1992).

Several authors (Casenave and Valentin, 1989 and 1992; Dexter, 2002; Fox et al., 2004) have also shown that soils with poor physical quality characterized by lack of structure or poor structure with less favourable pore types, i.e., small disconnected rounded pores, contribute to low water infiltration capacity, high runoff and poor aeration and rootability.

Even though the important role of the soil surface pore system in water flow, infiltration and erosion is well known, there is still little information about the porosity of soil crusts, especially for BSCs, which have been quantitatively investigated in only a few cases (Edwards et al, 1988; Malam Issa et al., 2009; Papadopoulos et al, 2009; VandenBygaart et al., 2000; Verrecchia et al., 1995). In some of those papers, and in other more general papers on crust formation, crust micromorphology ${ }^{1}$ is also described (Arshad and Mermut, 1988; Onofiok and Singer, 1984; Wakindiki and Ben-Hur, 2002). Given that pore size distribution, shape, and continuity have been found to be good indicators of soil physical quality (Pagliai and Vignozzi, 2002; Pagliai et al., 2004; Papadopoulos et al, 2009), assessment of 2Dporosity $^{3}$ by soil micromorphology ${ }^{1}$ and soil micromorphometry ${ }^{2}$ (in the sense given by Ferrari and Pagliai, 1980) has been used for physical soil characterisation (Papadopoulos et al., 2009; Protz and VandenBygaart, 1988; Rossi and Graham, 2009), soil management (Pagliai and Guidi, 1985; Pagliai et al., 2004; Grieve et al., 2005; Mooney and Morris, 2008; among others), characterising soil crusts, and understanding crust formation and its hydrological implications (Arshad and Mermut, 1988; Bresson and Boiffin, 1990; Valentin and Bresson, 1992; Wackindiki and Ben-Hur, 2002).

The use of 2D-porosity to assess the effects of soil crusts on soil quality is a new approach not yet developed. In this paper, the hypothesis tested is that the amount, shape, size and area of pores can be used as indicators of soil quality in natural crusted soils in semiarid areas. Better soil quality should be associated with evolved BSCs with high porosities and well-connected 
pores. Worse soil quality should be associated with either physical soil crusts or incipient biological crusts with low porosities and small, unconnected pores. The aims of this research are to describe and quantify the 2D-porosity of soil crusts in a semiarid ecosystem where crusts are the most important soil cover and to ascertain whether the characteristics of 2-D porosity of both soil crusts and the soil immediately beneath can be used as indicators of quality for natural crusted soils.

${ }^{1}$ Micromorphology $=$ suite of methods and techniques for the study of undisturbed soils in thin sections by optical microscopy (Kubiena, 1938). Modern micromorphological techniques also include electron microscopy (SEM, TEM), coupled or not coupled to X-ray diffraction, and many types of microprobes.

${ }^{2}$ Micromorphometry $=$ with reference to soil is the measurement of microscopic features (particles, aggregates, pores, etc.).

3 2-D porosity $=$ number, size, area and shape of pores in two dimensions of a material assessed either in thin sections or polished blocks, essentially by image analysis techniques.

\section{MATERIALS AND METHODS}

\section{Site description}

The study area is the Tabernas Desert, in the Sorbas-Tabernas basin, in the Province of Almería (SE Spain), surrounded by the Gador, Nevada, Filabres and Alhamilla Mountain Ranges in the Betic Chain (Figure 1). The basin fill is mainly soft Miocene, mostly gypsumcalcareous mudstone and calcareous sandstone (Cantón et al., 2001a), which, along with the Quaternary tectonics and the dry climate, have produced an extensive stepped landscape of multiple-age badlands separated by dissected pediment surfaces (Alexander et al., 1994). The climate is semiarid thermo-Mediterranean (Lázaro and Rey, 1990) with long, dry summers. The average annual temperature is $17.9^{\circ} \mathrm{C}$, with an absolute maximum of $45^{\circ} \mathrm{C}$, absolute minimum of $-4.5^{\circ} \mathrm{C}$, and a mean annual rainfall of $235 \mathrm{~mm}$, mostly in winter. Annual potential evapotranspiration is around $1500 \mathrm{~mm}$, indicating a considerable annual water deficit (Cantón et al., 2001b). The landscape is formed by asymmetric SE-NW valleys, where NE-facing slopes with gradients of nearly $30^{\circ}$ are carpeted by Endoleptic Regosols (FAO, 1998) or Lithic-xeric Torriorthent (Soil Taxonomy, 1999), mainly covered by lichen crusts (essentially Diploschistes diacapsis, Squamarina lentigera and Fulgensia fulgida). At the pediment, on gentle slope gradients, soils are thicker and formed by Haplic Calcisol (FAO, 
1998) or Xeric Haplocalcid (Soil Taxonomy, 1999) and covered by scattered perennial plants (with predominance of Helianthemun almeriense, Hammada articulata, Artemisia barrelieri, Salsola genistoides) with BSCs in open areas and patches of annual plants (predominated by Stipa capensis). SW-facing slopes are steeper (slope gradients up to $70^{\circ}$ ), with poorly developed soils, Epileptic Regosols (FAO, 1998) or Lithic Torriorthent (Soil Taxonomy, 1999), bare with PSCs or scarcely covered by lichens or annual plants (Cantón et al., 2003).

\section{Soil crust characteristics}

Cantón et al. (2004) had previously identified the main ground-cover types in the study site and demonstrated that their spatial distribution is strongly controlled by topography. The main soil crusts taken from those ground-cover types were defined as belonging to three different landforms and to five different soil units. The three landforms are: A) Hillslopes oriented S to W and covered with PSCs or with incipient biological crusts (IBCs), both types covering $38.5 \%$ of the total study area, though IBC are less abundant, representing only 5 to $10 \%$; B) Top of $\mathrm{N}$ to E-facing slopes covered with well-developed LC interspersed with a few shrubs in a landform representing 19.2\% of the total area, and C) Bottom of pediments and other open areas, dominated by scattered dwarf shrubs and/or annual plants interspersed with BSCs, covering $42.5 \%$ of the area. Therefore, all together, soil crusts cover more than $75 \%$ of the soil surface in the study area.

All the above soil crusts cover five different soil units in different stages of soil development (Cantón et al., 2003), and with different hydrological and erosion behaviour. However, as this paper focuses on crusted soils developed on gypsum-calcareous mudstone, the crusts from one of the soil units, which is developed on a mixed colluvial material (sandstone and mudstone), is not included, because its formation is affected by the sandstone.

The soil crusts in this study are described below, giving type of soil and crust:

1. PSC: physical soil crust. A mostly structural crust (Valentin and Bresson, 1992) covering Epileptic Regosols (Lithic Torriorthents) usually found on slopes with gradients of over $40^{\circ}$, and sometimes on slope gradients of less than $30^{\circ}$. It can also appear on SW pediments as a depositional crust (Valentin and Bresson, 1992) from a few millimetres to over 5-cm thick formed by silty micro-layers.

2. IBC: incipient biological crust, mostly dominated by cyanobacteria and pioneer lichens (Verrucaris cf. obductilis and Psorotichia sp.). It covers Epileptic Regosols (Lithic Torriorthents) when the soil is sufficiently stable (slope gradients between $30^{\circ}$ and $40^{\circ}$ ). 
3. LC: lichen crusts, subdivided in two main types: LC1, formed by Diploschistes diacapsis, Squamarina lentigera, Buellia zoharyi and Buellia epigaea as the most abundant species, carpeting about $80 \%$ of the surface along with a sparse cover of annual and perennial plants over Endoleptic Regosols (Lithic-xeric Torriorthents) in areas with slope gradients averaging $29^{\circ}$, with little soil development; b) LC2, formed by Diploschistes diacapsis, Squamarina lentigera and Fulgensia fulgida, non-lichen BSCs and scattered annual and perennial plants over Eutric Gypsisols (Lithic Haplogypsids), essentially in divides, on slope gradients $<20^{\circ}$ with a convex curvature, with quite small contributing areas (they receive water only from direct precipitation).

4. CVS: crusted vegetated surface. They cover open areas dominated by scattered dwarf shrubs and/or annual plants on Haplic Calcisols (Xeric Haplocalcid). These crusts are mostly cryptogamic, formed by cyanobacteria, mosses and lichens. They are also subdivided in two types: a) CVS1: thin cryptogamic and/or physical crusts in the spaces between shrubs and scarce annual plants on moderate slope gradients (average $21^{\circ}$ ), with relatively high infiltration and little erosion. These soil crusts are found over usually thicker and better developed soils than the other soil crusts; b) CVS2: thin cryptogamic crust developed over a physical crust, in areas with annual plants where the average slope gradient is $17^{\circ}$.

\section{Soil surface sampling and physicochemical properties}

Though soil surface crusts are sensus strictus only the surface layer of the soil, their relationship with the soil underneath is of paramount importance, and therefore, in the following sections, the term soil crust will be used in a wider sense to also include the soil immediately underneath $(0-3 \mathrm{~cm})$.

For physicochemical analysis, four bulk soil samples were collected from 0 to $3-\mathrm{cm}$ in each of the six soil units (PSC, IBC, LC1, LC2, CVS1, CVS2) at the beginning of the dry season.

For both soil micromorphology and micromophometry, two undisturbed, vertical samples were taken from 0 to 5 -cm in every soil unit with Kubiena boxes $(10 \times 7 \times 5 \mathrm{~cm})$ carefully pressing them against the ground with a flat rigid plate kept parallel to the soil surface, assuming that there was no internal disturbance if no cracks appeared on the surface crust during sampling.

Bulk soil samples were air-dried, gently crushed and passed through a 2-mm sieve to remove coarse fragments. 
Particle-size distribution was by the French standard (AFNOR NF X 31-107 in Legros, 2007), where 5 grain fractions are considered, coarse sand $(2-0.2 \mathrm{~mm})$, fine sand $(0.2-0.05 \mathrm{~mm})$, coarse silt $(0.05-0.02 \mathrm{~mm})$, fine silt $(0.02$ to $0.002 \mathrm{~mm})$ and clay $(<0.002 \mathrm{~mm})$, determined by sieving (fractions $>0.05 \mathrm{~mm}$ ) and sedimentation by the pipette method (fractions < $0.05 \mathrm{~mm}$ ) (Gee and Bauder, 1986). The following pretreatments were applied: a) removal of organic matter with $30 \% \mathrm{H}_{2} \mathrm{O}_{2}$, b) sulphate leaching with distilled water, c) removal of carbonates with $1 \mathrm{M} \mathrm{NaOAC}$ at $\mathrm{pH}$, and d) dispersion by shaking the sample in $10 \mathrm{~mL}$ of $40 \%$ sodium hexametaphosphate. The total organic C (TOC) content was determined by the Nelson and Sommers (1982) method. Water content (WC), at two different tensions, $-33 \mathrm{kPa}$ and $-1500 \mathrm{kPa}$, was calculated using pressure-plates on repacked, sieved fine earth samples (all samples treated the same to homogenize bulk density as much as possible, necessary for valid results according to Elrik \& Tanner, 1955). The calcium carbonate equivalent was found by rapid titration (Puri, 1930). Soil $\mathrm{pH}$ was measured in the saturation extract, and total gypsum by precipitation with $\mathrm{BaCl}_{2}$ (Porta, 1998). Soluble $\mathrm{Ca}^{2+}, \mathrm{Mg}^{2+}, \mathrm{Na}^{+}$, and $\mathrm{K}^{+}$in the saturation extract were measured by atomic absorption spectrophotometry and $\mathrm{SO}_{4}^{-2}$ by ion chromatography.

\section{Micromorphology}

Undisturbed soil samples were air dried at room temperature, and then impregnated under vacuum with an unsaturated polyester resin, in which a fluorescent dye (UVITEX-OB) was added, using high-grade acetone as a thinner (Murphy, 1986). After resin polymerization, i.e., hardening, the oriented blocks were cut perpendicular to the soil surface, into 1-cm-thick vertical slices with a diamond disk saw, yielding $5 \times 10-\mathrm{cm}$ sections. All faces were polished by $\mathrm{SiC}$ grit paper on a grinding wheel. A thin section was made from one slice of each block. Micromorphological descriptions followed the terminology proposed by Bullock et al (1985). 2-D pores were assessed from high-contrast photographs of vertical polished blocks where only the resin-filled pores appeared when illuminated with UV light (Torrentó and SoléBenet, 1992). Then the photographs were scanned and analyzed at a resolution of $30.3 \mu \mathrm{m}$ per pixel in a Leica Quantimet-570 image analysis system following the method of Pagliai et al. (1983). Automatic thresholding was employed as the contrasted photographs satisfactorily separated the soil from the pore phase. Results with this analytical system have been proven comparable to more recent image analysis systems used in other 2-D porosity studies, e.g., Josa et al., 2010. In every photograph, two $15.5-\mathrm{mm} \times 15.5-\mathrm{mm}$ regions of interest (ROI) near the soil surface and four ROIs per block were analysed and the data averaged. As the pixel 
size was $30.3 \mu \mathrm{m}$, the minimum visible pore was this size or larger, and consequently only mesopores $>50 \mu \mathrm{m}$ and macropores (Luxmoore et al, 1990), could be measured.

Meso-macropores were counted and measured in every ROI examined. The following variables were calculated in every ROI, which was always $2.4025 \mathrm{~cm}^{2}$ : a) number of mesomacropores per $\mathrm{cm}^{2}$ or NP (number of macropores in every ROI divided by its surface), $b$ ) meso-macroporosity or AP (area occupied by meso-macropores divided by the total ROI area, in percentage), c) pore shape in three classes according to the form factor calculated for every pore as Area/(Perimeter $)^{2}$. When the form factor was above 0.04 , the pores were labelled as rounded, between 0.015 and 0.04 irregular, and below 0.015 elongated (Bouma, 1977). Moreover, each pore shape class was then subdivided into eight size classes $(<100 \mu \mathrm{m}, 100-$ $200 \mu \mathrm{m}, \quad 200-300 \mu \mathrm{m}, \quad 300-400 \mu \mathrm{m}, \quad 400-500 \mu \mathrm{m}, \quad 500-1000 \mu \mathrm{m}, \quad 1000-1500 \mu \mathrm{m}, \quad 1500-$ $2000 \mu \mathrm{m}$, and $>2000 \mu \mathrm{m}$ ) which were grouped in three classes for the statistical analyses (< $100 \mu \mathrm{m}, 100$ to $1000 \mu \mathrm{m},>1000 \mu \mathrm{m})$. The $<100-\mu \mathrm{m}$ class was not included in the shape analysis because the shape of pores containing fewer than 9-10 pixels is uncertain. Total NP and total AP were measured for each sample (slices from blocks) as well as by shape and size class.

\section{Hydrological properties}

Soil crust response to natural rainfall was examined using $0.24 \mathrm{~m}^{2}$ bounded circular runoff plots (with no upslope run-on). The plots were connected to 50-L tanks, where total runoff and sediment yield were sampled after each rainfall event during three complete hydrological years (from October to September of the following year). Three plots were available for each soil crust type, except for CSV2 with only two plots. The plots were adjacent to the soil crusts sampled for this study. Rainfall data were provided by the meteorological station at the experimental field site (Cantón et al., 2001b). The variables available were mean annual infiltration coefficient (ratio of infiltration rate $(\mathrm{mm})$ to rainfall $(\mathrm{mm})$ and mean annual sediment yield for the 3-year monitoring period. Maximum and minimum infiltration coefficients per event were also available to explain specific infiltration behaviour.

\section{Statistics}

Physicochemical parameters, NP and AP from all soil crusts were first processed statistically to find out if there were significant differences among soil crust types. Therefore, after testing for normality and performing a one-way ANOVA, a Fisher's LSD as Multiple Range Test was done to check for significant differences among soil crusts. The various soil crusts were 
taken as classification variables and the physicochemical soil properties and pore characteristics (NP and AP, subdivided by their respective shape and size classes) as response variables. A further discriminant analysis allowed reducing all the studied crusts into a small number of crust groups with similar properties. All physicochemical parameter means were also tested for their Pearson's correlation with pore variables (NP and AP) to find any significant relationships between these two groups of variables. All statistical analyses were performed using Statgraphics Plus v.5.1 for Windows (2001) and Statistica v.6.0 (2001).

\section{RESULTS}

Physical and chemical properties of soil crusts

For all surfaces tested, silt (coarse plus fine) was the most abundant fraction (Table 1), followed by fine sand and clay.

WC at $-33 \mathrm{kPa}$ ranges from 22.2 to $30.5 \mathrm{~kg} \mathrm{~kg}^{-1}$ and WC at $-1500 \mathrm{kPa}$ from 7 to $10.9 \mathrm{~kg} \mathrm{~kg}^{-1}$, though there are no significant differences among the soil crusts. All soil crusts show a slightly alkaline $\mathrm{pH}$ ranging from 7.62 to 7.80 , without significant differences.

PSC and IBC had the lowest organic carbon content of all the soil crusts studied (Table 1). In general, these soil crusts have a weak structure. They also have the highest water content (WC) at $-1500 \mathrm{kPa}$, numerically, though not statistically (Table 1), due to their high gypsum content, as described by Eswaran and Zi-Tong (1991). Both soil crusts are also high in calcium carbonate content (242.7 $\mathrm{g} \mathrm{kg}^{-1}$ in PSC and $213.3 \mathrm{~g} \mathrm{~kg}^{-1}$ in IBC). $\mathrm{Mg}^{+2}, \mathrm{Na}^{+}, \mathrm{K}^{+}$and $\mathrm{SO}_{4}{ }^{-2}$ content are also the highest in IBC and PSC, while the $\mathrm{Ca}^{+2}$ ion is more abundant in CVS1, CVS2 and LC1 (Table 1). 
CVS1 and CVS2 have more organic matter content than the rest of the soil surfaces, ranging from $16.1 \mathrm{~g} \mathrm{~kg}^{-1}$ to $19.0 \mathrm{~g} \mathrm{~kg}^{-1}$ with well-developed soil structures. LC1 and LC2 both have higher organic carbon content (Table 1) than PSC and IBC, though somewhat higher in LC2, which has better soil structure and development, than LC1. Fine silt and clay are the most abundant particles in LC1 and LC2, and $\mathrm{WC}$ at $-1500 \mathrm{kPa}$ and $-33 \mathrm{kPa}$, respectively, are also similar in both, (Table 1). Calcium carbonate content is less abundant in LC2 than in the rest of soil surfaces, only $164.9 \mathrm{~g} \mathrm{~kg}^{-1}$, though statistically similar to CVS1.

\section{Description and quantification of pore characteristics}

Thin sections permitted observation of the overall soil microstructure in the different soil crusts (Fig 2). PSC is formed by a structural crust (Valentin and Bresson, 1992) over a very well developed depositional one (Valentin and Bresson, 1992). A dense layer formed by fine mineral particles with some small, unconnected vesicles and some cracks at the top can be observed as well as layering of fine particles and vesicles below the surface. IBC is an incipient biological crust near the bottom of a SW-oriented slope. It is formed by discontinuous biological elements over a physical, structural crust. The crusts itself is quite massive but just below there are many rounded unconnected pores and a few irregular and elongated pores, larger in size and poorly connected. LC1 is from a NE-oriented slope. The lichen is mostly detached from the soil beneath, leaving large elongated pores parallel to the soil surface. Below the crust, the soil fabric is very porous with some large, wellinterconnected irregular and elongated pores and rounded unconnected pores. LC2 is a lichen crust from a divide. The lichen is somewhat detached from the soil beneath it but not as much as in LC1. Interconnected irregular and elongated pores can be observed along with many unconnected rounded pores. CVS1, from the middle of NE-oriented slopes (pediment), formed over a well developed soil structure. Its fabric is highly porous with many large, interconnected rounded, elongated and irregular pores. CVS2, a mixed soil-crust type from the lower part of pediments, formed over a medium-grade soil structure. It contains many large, interconnected rounded, elongated and irregular pores (Fig 2).

$<$ Insert Figure 2 here $>$

IBC and PSC soil crusts have the lowest number of pores per $\mathrm{cm}^{2}$ (131 and 133, respectively), while CVS1 has the highest (367) (Table 2). By shape, most pores in all soil crusts are rounded, then irregular and least frequently elongated. 
AP also follows a similar trend with PSC and IBC (4.22\% and 3.45\%, respectively), having the lowest AP of all soil crusts (Table 3 ). The areas of the different pore shapes are not evenly distributed in these soil crusts. In PSC, most rounded pores are small $(<300 \mu \mathrm{m})$ as shown in Fig $3 a$.

LC2 has an intermediate NP (Table 2) though its AP (Table 3) is one of the largest of all soil crust types (23\%) along with LC1 (24\%). The number of pores with different shapes in these crusts is unevenly distributed following a decreasing sequence: rounded pores $>$ irregular pores $>$ elongated pores. The area from different pore shapes is also unevenly distributed (Fig 3b) but follows an increasing sequence: rounded pores $<$ irregular pores $<$ elongated pores.

AP in CVS1 and CVC2 is quite evenly distributed among the 3 pore shapes (Table 3 ). All crusts have the most pores in the $100-1000-\mu \mathrm{m}$ range and very few over $1000 \mu \mathrm{m}$. Moreover, AP is quite evenly distributed among the three pore shapes in the 100 to $1000-\mu \mathrm{m}$ range in the different subranges (Fig 3c) in contrast to LC1 soil crust, where most of the AP is in the 400$1000 \mu \mathrm{m}$ range and mainly elongated pores (Fig 3b).

The highest number of $>1000-\mu \mathrm{m}$ pores is irregular, and found in LC1 and CVS2 soil crusts (2.1 and 1.6 respectively). AP is also dominant in the $100-1000 \mu \mathrm{m}$ range. Irregular pores with the largest area, $>1000 \mu \mathrm{m}$, are found in soil crusts CVS2, LC1, and LC2, but the largest elongated pores are found only in LC1.

$<$ Insert Figure 3 here $>$

\section{Relationships between physicochemical properties and 2-D porosity}

Many significant Pearson's correlations were observed between physicochemical properties and 2-D porosity characteristics (Table 4). Properties positively correlated are TOC and coarse silt (Table 4). In contrast, properties negatively correlated with 2-Dporosity are coarse sand, gypsum, $\mathrm{Ca}^{2+}, \mathrm{K}^{+}$and $\mathrm{SO}_{4}{ }^{2-}$, which usually do not favour good soil structure (Table 4). Specific pore shapes and sizes show particular relationships with physicochemical parameters. The number of pores of any size and pore shape is positively correlated with TOC. However, only the largest AP of irregular pores is positively correlated with TOC. AP between 100 and $1000 \mu \mathrm{m}$, of any shape, is negatively correlated with coarse sand.

\section{Differences among soil crust types and further grouping}

The results of ANOVA and further Multiple Range Tests are presented in Tables 1, 2 and 3. 
In general there are few significant differences between PSC and IBC soil crusts (only coarse sand and gypsum content are significantly different). However, these soil crusts show significant differences with the rest of soil crusts (LC1, LC2, CVS1 and CVS2). These differences refer to some physicochemical variables (TOC, $\mathrm{CaCO}_{3}, \mathrm{Ca}^{2+}, \mathrm{Na}^{+}, \mathrm{SO}_{4}{ }^{2-}$ from Table 1) and to some NP and AP variables (e.g. AP, AEP and AEP 100-1000 $\mu \mathrm{m}$ from Table $3)$.

Similarly there are few significant differences between LC1 and LC2 (only $\mathrm{CaCO}_{3}$ and $\mathrm{Na}^{+}$ show significant differences) but some significant differences between these two soil crusts and PSC, IBC, CVS, and CVS2 (Tables 1, 2, 3).

CVS1 and CVS2 also showed numerical differences with PSC, IBC, LC1 and LC2 in most of the variables (Tables 1, 2 and 3 ) but they only differ significantly $(\mathrm{P}<0.05)$ in AP, AEP and AEP 100-1000 $\mu \mathrm{m}$ (Table 3).

Consequently, it would be possible to gather the six soil crusts into 3 groups, each one with some similar physico-chemical properties and some similar 2-D pore characteristics (NP and AP). Group 1 will gather PSC and IBC; Group 2, LC1 and LC2; and Group 3, CVS1 and CVS2. In order to test the validity of such grouping, a factorial discriminant analysis was performed. The three groups of soil crusts were considered as classification factors and the physicochemical properties showing significant differences among crust groups (Table 1) and AP properties (Table 3) as independent variables. Fig 4 shows the corresponding scatter diagram where the three predefined groups were clearly differentiated with $100 \%$ of the cases correctly classified.

\section{Hydrological behaviour of the soil crusts}

Average annual infiltration coefficients for the six soil crust types ranged from $63.3 \%$ to $78 \%$, though without noticeable differences. This might be because annual averages also included many small rainfall events which did not produce any runoff or yielded negligible volumes. However, the differences among soil crusts became noticeable (Table 5) for rainfall events with intensities over $30 \mathrm{~mm} / \mathrm{h}$, when infiltration coefficients ranged from $47.3 \%$ to $86 \%$ (Table 5, event 1). The highest infiltration was recorded in CSV crusts and the lowest in PSC. Under low rainfall intensities, the behaviour of the different soil crusts tended to be homogeneous, as it was more dependent on soil matrix behaviour than the crust. However, under high rainfall intensities soil crusts and their specific morphologies behave differently. PSC behaved as seals in which unconnected rounded pores, mostly vesicles, drastically reduced infiltration capacity. IBC, as an intermediate type between physical and biological 
soil crust, had an intermediate behaviour. LC1 may behave differently depending on how close lichen contact with the substrate is. When close contact is predominant, infiltration can be high as in LC2, whereas, when lichens are mostly detached from the substrate, they act as roofs, preventing infiltration and enhancing runoff. CSV soil crusts are usually found on soils with higher OC content, and consequently soil structure, and thereby infiltration, is better.

\section{DISCUSSION}

The statistical analysis based on ANOVA and Multiple Range Tests (Tables 1, 2, 3) showed that three groups of soils crusts were possible based on the physico-chemical and 2-D porosity similarities and differences between pairs of soil crusts. These 3 groups were also confirmed by discriminant analysis (Figure 4) where the three groups of soil crusts were considered as discriminant factors, showing that soil-crusts groups were correctly classified.

These groups of soil crusts could therefore be associated with comparatively distinct soil properties and hydrological behaviour.

In the following section, these three different groups and their 2-D porosity characteristics are explained with their physicochemical properties in order to verify the hypothesis that 2D-pore characteristics (based on amount, shape, size, and area occupied by pores) can be used as indicators of soil quality in crusted, natural soils from semiarid regions.

Group 1, formed by soil crusts PSC and IBC, has the lowest total porosity of the three groups, both in number of pores (NP) and meso-macroporosity (AP). The most abundant are 100 to $1000 \mu \mathrm{m}$ rounded pores (Table 2). Most of these are vesicles (Fig 2) which are usually formed by splash as reported by other authors (Moore and Singer, 1990; Zhan and Miller, 1996; Bajracharya and Lal, 1998). These soil crusts hardly have any intermediate or large pores, a fact attributed to their breaking up into smaller rounded pores under the compacting effect of raindrops, as suggested by Fox et al (2004). The comparatively high fine silt content and low organic matter of these soil crusts (Table 1) seem to contribute to a massive structure with a denser low-porosity layer. The higher coarse sand content could also contribute to a decrease in aggregate stability due to the larger grain size and the lower reactivity of sand grains (Table 4 shows the negative correlations between coarse sand and the area occupied by pores, especially rounded and elongated pores, mostly between 100 and $1000 \mu \mathrm{m})$. The high carbonate and gypsum content, which could act as the key binding agent in these soils, seems to have a negative effect on their porosity, as suggested by the negative correlations between 
gypsum, $\mathrm{SO}_{4}^{-2}$ and $\mathrm{Ca}^{2+}$ content and several porosity variables (Table 4). Miralles et al. (2009) also found that soils with high calcium carbonate and/or other simple salts, though belonging to another semiarid Mediterranean environment in SE Spain, had lower total porosity.

The Group 1 pore system may explain the low infiltration rate in such soil, especially under rain of moderate to high intensity, and its concurrent high erosion rate (Table 5), as shown in previous papers in the same area (Solé-Benet et al., 1997; Cantón et al., 2001b; Cantón et al., 2002). As explained by Valentin (1991), small rounded pores are less effective in transmitting water than irregular and elongated pores, because by Poiseuille's Law, water flow is extremely sensitive to pore diameter. Therefore, low infiltrability is not only due to the lower total porosity of the soil crusts, but also to a particular distribution of pore shapes and sizes. As shown in Table 5, the differences from the rest of the soil crusts are especially pronounced for intense rainfalls at event scale, although annual differences are smaller due to the effect of frequent small rains that generate negligible runoff regardless of the soil crusts. Cantón et al (2001a) found a rainfall threshold of about $3 \mathrm{~mm}$ was required to produce runoff at the plot scale and rainfall of less than $3 \mathrm{~mm}$ represents $67 \%$ of annual rainfall at this site (Cantón et al., 2001b). When these light rains start to fall after a dry period, the added effect of very frequent vertical cracks contributes significantly to total infiltration (Table 5). However, with heavy rainfall, these cracks are quickly sealed as soil gets wet, decreasing the infiltration rate again, as found by Li et al., (2005) and Solé-Benet et al., (1997) in similar soil crusts at this site.

Group 2, formed by soil crusts LC1 and LC2, has the highest AP (up to 23.65\%) of the three groups, though NP (193 to 291) is similar to Group 3. The higher AP in these soil crusts is mostly due to the predominance of elongated, interconnected pores (Table 3), a large part of which are between the detached lichen and the substrate underneath it (Fig 2). This pore system, with higher AP than Groups 1 and 3, does not connect the surface with the soil underneath and therefore does not favour infiltration. However, in spite of this enhanced runoff, the armouring effect of lichens decreases erosion rates (Table 5). Several studies have shown how trapping and binding by the living filaments of microorganisms forming BSCs, favour soil particle aggregation and provide soil cohesion (Cameron and Devaney, 1970; Belnap and Gardner, 1993; Cantón et al., 2004; Malam Issa et al., 2009). This cohesion stabilizes soil against water erosion. 
Group 3 (CVS1-CVS2), shows a 2-D porosity pattern similar to the one in Group 2 (Figure 2). Their well-developed structure may be attributed to the fact that they have the highest organic matter content from abundant annual plants, shrubs and inter-shrub BSCs, and also the highest fine sand and coarse silt content (Table 1). It also has the highest total number of pores with a large number of rounded pores of various diameters and large interconnected irregular and elongated pores (Figure 2). Rounded pores of all sizes up to $1000-\mu \mathrm{m}$ diameter are also quite evenly distributed in Group 3 (Fig 3c), where much larger rounded pores may be observed than in Groups 1 and 2 (Fig 3). In addition to the hypothesis on rounded pore formation (purely mechanical), rounded, irregular and elongated pores might also be due to biological activity linked to biological crusts (lichens, cyanobacteria and other microbiotic organisms), as described elsewhere by other authors like Stanier and Cohen-Bazire (1977), Decho (1990), Kidron et al.(1999). According to Malam Issa et al. (2009), some of these types of pores could be caused by bacterial filaments, hydrophilic polymers (polysaccharides) and hydrophobic (glycoproteins and lipopolysaccharides) molecules in microbiotic crusts. Both hydrophilic and hydrophobic components confer adhesive properties that make filaments able to adhere to and bind soil particles, thereby affecting the soil's spatial organisation. Furthermore, large rounded and elongated pores are also more frequent and occupy larger areas in this group, especially in CVS2, than in the rest of the soil crusts, which may be mainly due to the action of very fine roots from annual plants and even to soil mesofauna (earthworms and arthropods) that build galleries or tunnels.

As in Group 2, size, shape and connectivity of pores in Group 3 may affect water flow through the soil. In fact, CVS1 and CVS2 did show higher infiltration rates than LC1, PSC or IBC (Table 5). Nevertheless, despite the lower infiltration rates in LC1, soil crusts with microbiotic cover play an important role in the conservation and improvement of soil properties. Hence, BSCs have a direct impact on soil erosion reduction and favour soil water retention/transit, and their role is therefore crucial in Mediterranean arid and semiarid regions, where according to the International Union of Soil Scientists (IUSS), Commission VIII "Soil and the Environment", one of the main environmental problems is the threat of progressive desertification due to erosion and water deficit in soils (Sánchez-Marañón et al., 2002; Miralles, 2007). Moreover, keeping in mind that BSCs increase available nutrients in the soil by concentrating essential elements, such as nitrogen and carbon (Harper and Pendleton, 1993), their abundance and distribution could serve as soil quality indicators, especially in the more fragile ecosystems where human or environmental disturbances are common, as in many arid and semiarid zones. 


\section{CONCLUSIONS}

Soil micromorphology and micromorphometry of meso- and macropores have proven to be reliable methodology suites for differentiating soil crusts in a semiarid rangeland. Soil crusts associated with different physicochemical soil properties in the upper centimetres of soils are related to different degrees of soil development. Infiltration and soil erosion behave differently in the various crust types and the soil underneath them, and therefore the soil quality also differs. The significant statistical relationships among physicochemical properties with 2-D porosity of soil crusts, suggests that 2-D pore properties can be used as soil quality indicators in such environments.

High organic C content are associated to biological soil crusts and pore-systems with large, interconnected, elongated and irregular pores. On the contrary, physical crusts and incipient biological crusts have meso-macropore systems with few small unconnected rounded pores. The low infiltrability of these physical and incipient biological crusts is not only due to the lower total porosity, but also to the particular distribution of pore shapes and sizes.

However, the soil crusts with the highest meso-macroporosity are not always associated to the most developed soils. Such soil crusts, e.g. crustose lichens, are often detached to the soil beneath and, while providing the highest meso-macroporosity, such pore system does not connect the surface with the soil and does not favour infiltration.

Therefore, the number of pores, pore size, shape and area of soil crusts could be considered useful indicators of soil quality. However, to extrapolate this to a wider range of soil crusts, a much larger and more comprehensive range of soil surface crusts should be analyzed.

\section{ACKNOWLEDGMENTS}

The research described in this paper was partly conducted in the framework of several research projects funded by different organisations: a) the Spanish National R+D Programme: Project PROBASE (CGL2006-11619/HID), b) Junta de Andalucia (Andalusian Regional Government): Project RNM-3614, Efectos de las costras físicas y biológicas del suelo sobre el balance de agua y la erosión en ambientes semiáridos (Effects of physical and biological soil crusts on water balance and erosion in semiarid environments.) and Project P06-RNM01732, Balance hídrico en zonas degradadas semiáridas (Water balance in degraded semiarid zones), c) the EC-DG RTD- $6^{\text {th }}$ Framework Research Programme (sub-priority 1.1.6.3) Research on Desertification - project DESIRE (037046): Desertification Mitigation and Remediation of land - a global approach for local Solutions, d) RESEL (agreement between the Directorate General for Nature Conservation and the CSIC) and e) CSIC-CNR agreement (Spain-Italy): Project 1999PL0003. Michele Lamarca provided essential help in the use of Quantimet, Alfredo Durán and Montse Guerrero contributed indispensable field and 
laboratory work. We especially thank the Viciana family, owners of the study area, for granting permission to use their property as scientific experimental site. The authors are grateful to the Associate Editor and anonymous reviewers of the Soil Sci. Soc. Am. J., whose comments and suggestions greatly improved the quality of the paper.

\section{REFERENCES}

Alexander, R.W., A.M. Harvey, A. Calvo, P.A. James, and A. Cerda. 1994. Natural Stabilisation Mechanisms on Badland Slopes: Tabernas, Almeria, Spain. In: Millington, A.C. and Pye, K. (eds.), Enviromental Change in Drylands:Biogeographical and Geomorphological perspectives. John Wiley and sons, Ltd, pp. 85-111.

Arshad, M.A., and Mermut, A.R. 1988. Micromorphological and physico-chemical characteristics of soil crust types in Northwestern Alberta, Canada. Soil Sci. Soc. Am. J. 52:724-729.

Assouline, S. and Y. Mualem. 2000, Modeling the dynamics of soil seal formation: analysis of the effect of soil and rainfall properties. Water Resour. Res. 36:2341-2349.

Azooz, R.H., and M.A. Arshad. 1996. Soil infiltration and hydraulic conductivity under longterm no-tillage and conventional tillage systems. Can. J. Soil Sci. 76:143-152.

Bajracharya, R.M., and R. Lal. 1998. Crusting effects on erosion processes under simulated rainfall on a tropical Alfisol. Hydrol. Process 12:1927-1938.

Ball, B.C., T. Batey, and L.J. Munkholm. 2007. Field assessment of soil structural quality- a development of the Peerlkamp test. Soil Use Manage. 23:329-337.

Belnap, J., and J.S. Gardner. 1993. Soil microstructure in soils of the Colorado Plateau: the role of the cyanobacterium Microcoleus vaginatus. Great Basin Naturalist 53, pp. 40-47.

Belnap, J. 1995. Surface disturbances: Their role in accelerating desertification. Environ. Monit. Assess. 37:39-57.

Belnap J., and D.A. Gillette. 1998. Vulnerability of desert biological soil crusts to wind erosion: The influences of crust development, soil texture, and disturbance. J. Arid Environ. 39:133-142.

Belnap, J., J.H. Kaltenecker, R. Rosentreter, J. Williams, S. Leonard, and D. Eldridge. 2001. Biological soil crusts: Ecology and management, Technical Reference 1730-2P

Belnap, J. 2006. The potential roles of biological soil crusts in dryland hydrologic cycles Hydrol. Process. 20:3159-3178. 
Beymer, R.J., and J.M. Klopatek. 1991. Potential contribution of carbon by microphytic crusts in pinion-juniper woodlands. Arid Soil Res. Rehabil. 5:187-198.

Bhattacharyya, R., V. Praksh, S. Kundu, and H.S. Gupta. 2006. Effect of tillage and crop rotations on pore size distribution and soil hydraulic conductivity in sandy clay loam soil of the Indian Himalayas. Soil Tillage Res. 86:129-140.

Bouma, J. 1981. Soil micromorphology and preferential flow along macropores. Agric. Water Manag. 3:235-250

Bresson, L.M., and J. Boiffin. 1990. Morphological characterization of soil crust development stages on an experimental field. Geoderma 47:301-325.

Bullock, P., N. Fédoroff, A. Jongerius, G. Stoops, and T. Tursina. 1985. Handbook for Soil Thin Section Description. Waine Research, Wolverhampton (UK), 152 p.

Cameron, R.E., and J.R. Devaney. 1970. Antarctic soil algal crusts: scanning electron and optical microscope study. Trans. Am. Microsc. Soc. 89:264-273.

Cantón,Y., A. Solé-Benet, I. Queralt, and R. Pini. 2001a. Weathering of a gypsum-calcareous mudstone under semi-arid environment at Tabernas, SE Spain: laboratory and field-based experimental approaches. Catena 44:111-132.

Cantón, Y., F. Domingo, A. Solé-Benet, and J. Puigdefábregas. 2001b. Hydrological and erosion response of a badlands system in semiarid SE Spain. J. Hydrol. 252:65-84.

Cantón, Y., F. Domingo, A. Solé-Benet, and J. Puigdefábregas. 2002. Influence of soil surface types on the overall runoff of the Tabernas badlands (SE Spain). Field data and model approaches. Hydrol. Process. 16:2621-2643.

Cantón, Y., A. Solé-Benet, and R. Lázaro. 2003. Soil-geomorphology relations in gypsiferous materials of the Tabernas Desert (Almería, SE Spain). Geoderma 115:193-222.

Cantón, Y., A. Solé-Benet, and F. Domingo. 2004. Temporal and spatial patterns of soil moisture in semiarid badlands of SE Spain. J. Hydrol. 285:199-214.

Casenave, A., and C. Valentin. 1989. Les états de surface de la zone sahélienne. Influence sur l'infiltration. ORSTOM, Collection "Didactiques". pp. 230.

Casenave, A., and C. Valentin. 1992. A runoff capability classification system based on surface features criteria in semiarid areas of West Africa. J. Hydrol. 130:231-249. 
Cavalieri, K.M., A. da Silva, C.A. Tormena, T.P. Leão, A.R. Dexter, and I. Hakansson. 2009. Long-term effects of no-tillage on dynamic soil physical properties in a Rhodic Ferrasol in Paraná, Brazil. Soil Tillage Res. 103:158-164.

Decho, A.W. 1990. Microbial exopolymer secretions in ocean environments: their role(s) in food webs and marine processes. Oceanogr. Mar. Biol. 28:73-153.

Dexter, A.R. 2002. Soil structure: the key to soil function. Adv. Geoecol. 35:57-69.

Dexter, A.R. 2004. Soil physical quality. Part I. Theory, effects of soil texture, density, and organic matter, and effects on root growth. Geoderma 120:201-214.

Douglas, J.T. 1986. Macroporosity and permeability of some soil core from England and France. Geoderma 37:221-231.

Edwards, W.M., M.J. Shipitalo, and L.D. Norton. 1988. Contribution of macroporosity to infiltration into a continuous corn no-tilled watershed: implications for contaminant movement. J. Contam. Hydrol. 3:205-193.

Eswaran, H., and G. Zi-Tong. 1991. Properties, genesis, classification, and distribution of soils with gypsum. In: Nettleton, W.D. (Ed.), Occurrence, Characteristics, and Genesis of Carbonate, Gypsum, and Silica Accumulations in Soils. SSSA Special Publication, vol. 26. Soil Science Society of America, Madison, WI, USA, pp. 89-119.

FAO-ISRIC- ISSS, 1998. World Reference Base for Soil Resources. FAO, Rome.

Fox, D.M., R.B. Bryan, and C.A. Fox. 2004. Changes in pore characteristics with depth for structural crusts. Geoderma 120:109-120.

Gee, G.W. and J.W. Bauder. 1986. Particle -size analysis. In American Society of AgronomySoil Science Society of America. Methods of soil analysis, part 1, Physical and mineralogical methods. Agronomy monograph, 9 ( 2nd. edition): 383-411. ASA, Madison, Wi, USA.

Germann, P., and K. Beven. 1981. Water flow in soil macropores: I. An experimental approach. J. Soil Sci. 32:1-13.

Greenland, D.T. 1977. Soil damage by intensive arable cultivation: temporary or permanent? Philos. Trans. R. Soc. Lond. 281:193-208.

Grieve, I.C., D.A. Davidson, and P.M.C. Bruneau. 2005. Effects of liming on void space and aggregation in an upland grassland soil. Geoderma 125:39-48. 
Harper, K.T., and R. Pendleton. 1993. Cyanobacteria and cyanolichens: can they enhance availability of essential minerals for higher plants? Great Basin Naturalist 53:59-72.

Hartemink, A.E. 1998. Soil chemical and physical properties as indicators of sustainable land management under sugar cane in Papua New Guinea. Geoderma 85:283-306.

Josa, R., M. Ginovart, and A. Solé. 2010. Effects of two tillage techniques on soil macroporosity in sub-humid environment. Int. Agrophys. 24:139-147.

Jurgensen, M.F., A.E. Harrey, R.T. Graham, D.S. Page-Dumroese, J.R. Tann, M.J. Larse, and T.B. Jain. 1996. Impact of timber harvesting on soil organic matter, nitrogen productivity and health of inland Northwest forest. For. Sci. 43:234-240.

Kidron, G.J., D.H, Yaalon, and A. Vonshak. 1999. Two causes for runoff initiation on microbiotic crusts: hydrophobicity and pore clogging. Soil Sci. 164:18-27.

Lázaro, R., and J.M. Rey. 1990. Sobre el clima de la provincia de Almería (SE Ibérico): primer ensayo de cartografía automática de medias anuales de temperatura y precipitación. Suelo y Planta 1:61-68.

Legros, J.P. 2007. Les grands sols du monde. Presses polytechniques et universitaires romandes, Lausanne (Switzerland), p. 574.

Li, X.Y., A. González, and A. Solé-Benet. 2005. Laboratory methods for the estimation of infiltration rate of soil crusts in the Tabernas Desert badlands. Catena 60:255-266.

Luxmoore, R.J. 1981. Micro-, meso-, and macroporosity of soil. Soil Sci. Soc. Am. J. 45:671672.

Luxmoore, R.J., P.M. Jardine, G.V. Wilson, J.R. Jones, L.W. Zelazny. 1990. Physical and chemical controls of preferred path flow through a forested hillslope. Geoderma 46:139154.

Malam Issa, O., C. Défarge, J. Trichet, C. Valentin, and J.L. Rajot. 2009. Microbiotic soil crusts in the Sahel of Western Niger and their influence on soil porosity and water dynamics. Catena 77:48-55.

Miralles, I. 2007. Calidad de Suelos en Ambientes Calizos Mediterráneos: Parque Natural Sierra María-Los Vélez. Ph.D. Thesis. University of Granada, Spain. 
Miralles, I., R. Ortega, G. Almendros, M. Sánchez-Marañón, and M. Soriano. 2009. Soil quality and organic carbon ratios in mountain agroecosystems of South-east Spain. Geoderma 150:120-128.

Mooney, S.J. and C. Morris. 2008. A morphological approach to understanding preferential flow using image analysis with dye tracers and X-ray Computed Tomography. Catena 73: 204-211.

Moore, D.C., and M.J. Singer. 1990. Crust formation effects on soil erosion processes. Soil Sci. Soc. Am. J. 54:1117-1123.

Murphy, C.P. 1986. Thin section preparation of soils and sediments. AB Academic Publishers, Berhamsted, UK. 149 p.

Nelson, D.W., and L.E. Sommers. 1982. Total carbon, organic carbon, and organic matter. In: Page, L.A., Miller, R.H., Kenney, D.R. (Eds.), Methods of Soil Analysis: Part 2. Chemical and Microbiological Methods, 2nd ed. American Society of Agronomy, Madison, WI, pp. $539-579$.

NRCS. 1996. Soil Quality Indicators: Soil Crusts. Soil Quality Information Sheet, April 1996, USDA, Washington, D.C., USA, 2 p.

Onofiok, O., and M. Singer. 1984. Scanning electron microscope studies of surface crusts formed by simulated rainfall. Soil Sci. Soc. Am. J. 48:1137-1143.

Pagliai, M., M. La Marca, and G. Lucamante. 1983. Micromorphometric and micromorphological investigations of a clay loam soil in viticulture under zero and conventional tillage. J. Soil Sci. 34:391-403.

Pagliai, M., and G. Guidi. 1985. Surface crusts and soil management in different types of soils. In Callebaut, S., Gabriels, D., and De Boodt, M. (eds) Proceedings of the symposium "Assessment of soil surface sealing and crusting", pp 363-366, Department of Soil Physics, University of Ghent. Belgium.

Pagliai, M. 1987. Effects of different management practices on soil structure and surface crusting. In: Fedoroff, N., Bresson, L.M., Courty, M. (eds.), Micromorphologie des Sols, Paris.

Pagliai, M., and N. Vignozzi. 2002. Soil pore system as an indicator of soil quality. In: Pagliai, M., Jones, R. (eds.), Sustainable Land Management—Environmental Protection- 
A Soil Physical Approach. Advances in GeoEcology, vol. 35. Catena Verlag, Reiskirchen, pp. $71-82.598$ pp.

Pagliai, M., N. Vignozzi, and S. Pellegrini. 2004. Soil structure and the effect of management practices. Soil Tillage Res. 79:131-143.

Papadopoulos, A., A.P. Whitmore, R.P. White, S.J. Mooney, N.R.A. Bird. 2009. Combining spatial resolutions in the multiscale analysis of soil pore-size distributions. Vadose Zone J. $8: 227-232$

Panini, T., D. Torri, S. Pellegrini, M. Pagliai, and M.P. Salavador Sanchis. 1997. A theoretical approach to soil porosity and sealing development using simulated rainstorms. Catena $31: 199-218$.

Protz, R., and A.J. VandenBygaart. 1998. Towards systematic image analysis in the study of soil micromorphology. Science of Soils (web journal) 3-4.

Porta, J. 1998. Methodologies for the analysis and characterization of gypsum in soils: a review. Geoderma 87:31-46.

Puri, A.N. 1930. A method of estimating total carbonates in soils. Bulletin No. 7. Imperial Agricultural Research Institute, Pusa.

Reynolds, J.F., D.M. Stafford Smith, E.F. Lambin, B.L. Turner, M. Mortimore, S.P. Batterbury, T.E. Downing, H. Dowlatabadi, R.J. Fernández, J.E. Herrick, E. HuberSannwald, H. Jiang, R. Leemans, T. Lynam, F.T. Maestre, M. Ayarza, and B. Walker. 2007. Global Desertification: Building a Science for Dryland Development. Science, 316:847-851.

Rossi, A.M., and R.C. Graham. 2010. Weathering and porosity formation in subsoil granitic clasts, Bishp crekk moraines, California. Soil Sci. Soc. Am. J. 74:172-185.

Sahani, U., and N. Behera. 2001. Impact of deforestation on soil physicochemical characteristics, microbial biomass and microbial activity of tropical soil. Land Degradation \& Development 12:93-105.

Sánchez-Marañón, M., M. Soriano, G. Delgado, and R. Delgado. 2002. Soil Quality in Mediterranean Mountain Environments: Effects of Land Use Change. Soil Sci. Soc. Am. J. 66:948-957. 
Singh, K.P., and S.K. Tripathy. 1992. Restoration of degraded forest system. In: Singh, J.S. (Ed.), Restoration of Degraded Land: Concept and Strategy. Meerut.

Soil Survey Staff, 1999. Soil Taxonomy: A Basic System of Soil Classification for Making and Interpreting Soil Surveys. Agricultural handbook, No 436. USDA, Washington, DC.

Solé-Benet, A., A. Calvo, A. Cerdá, R. Lázaro, R. Pini, and J. Barbero. 1997. Influences of micro-relief patterns and plant cover on runoff related processes in badlands from Tabernas (SE Spain). Catena 31:23-38.

Stanier, R.Y., and G. Cohen-Bazire. 1977. Phototrophic prokaryotes: the cyanobacteria. Annu. Rev. Microbiol. 31:225-274.

Torrentó, J.R., and A. Solé-Benet. 1992. Soil macroporosity evaluated by a fast imageanalysis technique in differently managed soils. Comm.Soil Sci. Plant Anal 23:1229-1244.

Valentin, C. 1991. Surface crusting in two alluvial soils of northern Niger. Geoderma 48: 201222.

Valentin, C., and L.M. Bresson. 1992. Morphology, genesis and classification of surface crusts in loamy and sandy soils. Geoderma 55:225-245.

VandenBygaart, A.J., R. Protz, A.D. Tomlin, and J.J. Miller. 2000. Tillage system effects on near-surface soil morphology: observations from the landscape to micro-scale in silt loam soils of southwestern Ontario. Soil Tillage Res. 51:139-149.

Verrecchia, E., A. Yair, G.J. Kidron, and K. Verrecchia. 1995. Physical properties of the psammophile cryptogamic crust and their consequences to the water regime of sandy soils, north-western Negev desert, Israël. J. Arid. Environ. 29:427-437.

Wakindiki, I.I.C., and M. Ben-Hur. 2002. Soil mineralogy and texture effects on crust micromorphology, infiltration and erosion. Soil Sci. Soc. Am. J. 66:897-905.

Zhan, X.C., and P.C. Miller. 1996. Physical and chemical crusting processes affecting runoff and erosion in furrows. Soil Sci. Soc. Am. J. 60:860-865. 


\section{Figure captions}

Figure 1: Map showing geographic location of the study area with the different crusted soil surfaces in SE-NW-oriented valleys. Legend: PSC = physical soil crust; IBC = incipient biological crust; $\mathrm{LC}=$ lichen crust; CVS $=$ mixed crusted surface.

Figure 2: Photographs of thin sections of the crusted soil surfaces in the study area, where the general soil structure can be observed in plain light: a) Physical soil crust, PSC, formed by a structural crust over a very well-developed depositional one. Observe a dense layer formed by fine mineral particles (FP) with some small disconnected rounded pores (vesicles V) and cracks (C) at the top, and layered fine particles (LP) and vesicles below the surface. b) View of an incipient biological crust (IBC) near the bottom of a SW-oriented slope with many rounded unconnected pores (vesicles V) in the upper part and few irregular (I) pores in the middle part. c) Lichen crust, LC1, from a NE-oriented slope. Lichen (LC) is mostly detached from the soil beneath it; large elongated (E) pores quite connected and few rounded pores (V). d) Lichen crust, LC2, from a divide; the lichen is somewhat detached from the soil beneath it; as in LC1, interconnected irregular (I) and elongated (E) pores can be observed. e) Mixed crusted surface, CVS1, formed by mosses, lichens and cyanobacteria, from the middle of NEoriented slopes (pediment) over a well-developed soil structure. The fabric is highly porous with many large, interconnected, elongated (E) and irregular pores. f) Mixed crusted surface, CVS2, formed by lichens (LC), mosses and cyanobacteria, from the bottom of pediments over a medium-grade soil structure; some large and fine interconnected, elongated (E) pores can be observed and some rounded unconnected pores (R). The black bars are $10 \mathrm{~mm}$ in all photographs.

Figure 3: Relative percentages of AP (area of meso-macropores) considering shape and size (between 100 and $1000 \mu \mathrm{m}$ ) for PSC (3a), LC1 (3b) and CSV1 (3c) soil crusts.

Figure 4: Scatter diagram from the discriminant analysis with the 3 groups of soil crusts as classification factors. Independent variables were TOC, coarse sand, gypsum, ARP 100-1000 $\mu \mathrm{m}$, ARP $>1000 \mu \mathrm{m}$, AIP 100-1000 $\mu \mathrm{m}$, AIP $>1000 \mu \mathrm{m}$. 100\% cases correctly classified. P $=0.0000$ for both function 1 and function 2 . 
Figure 1

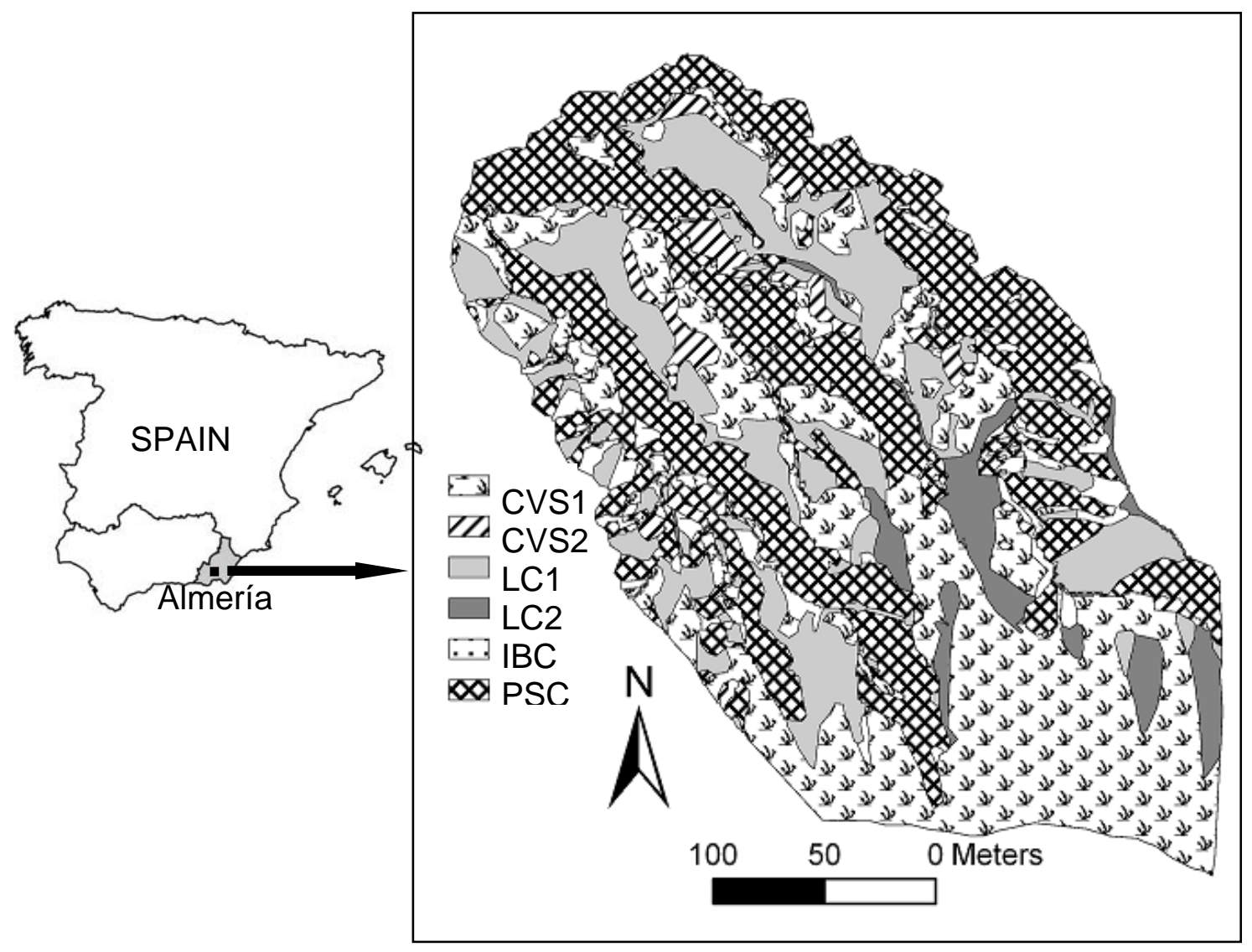

Figure 2 


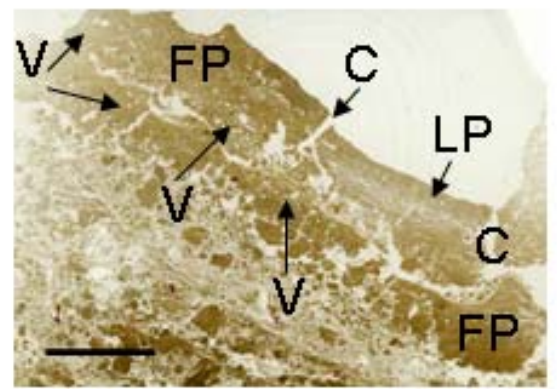

a

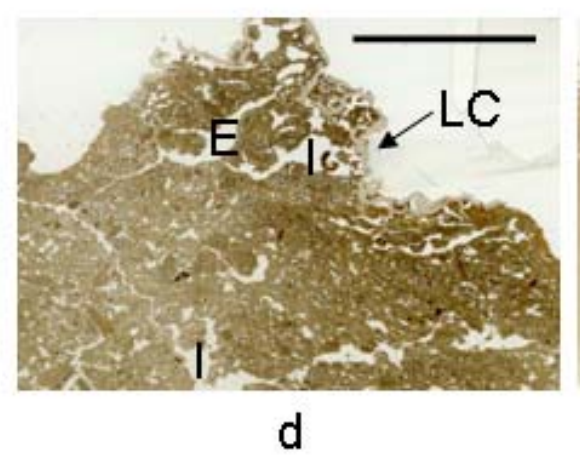

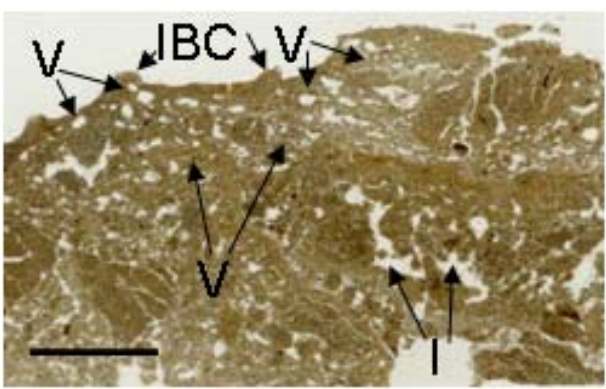

b

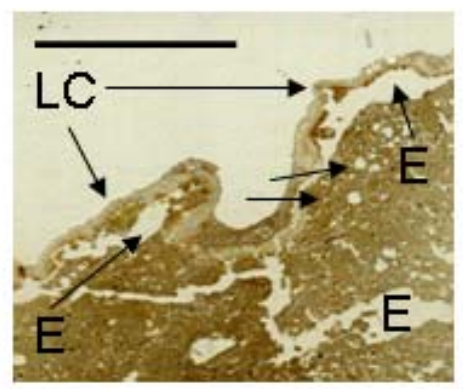

C

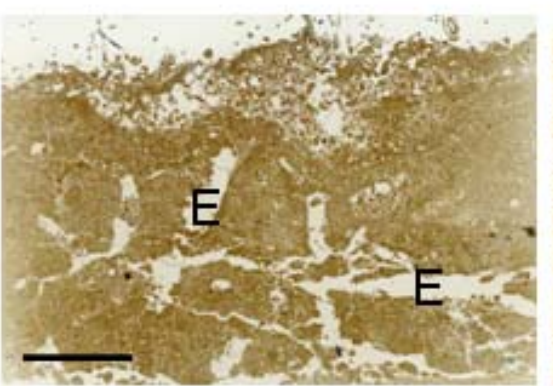

e

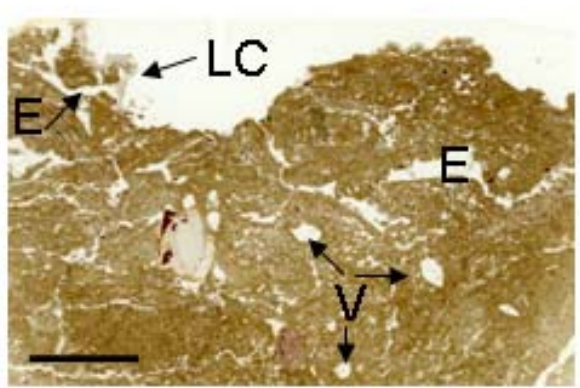

f 
Figure 3
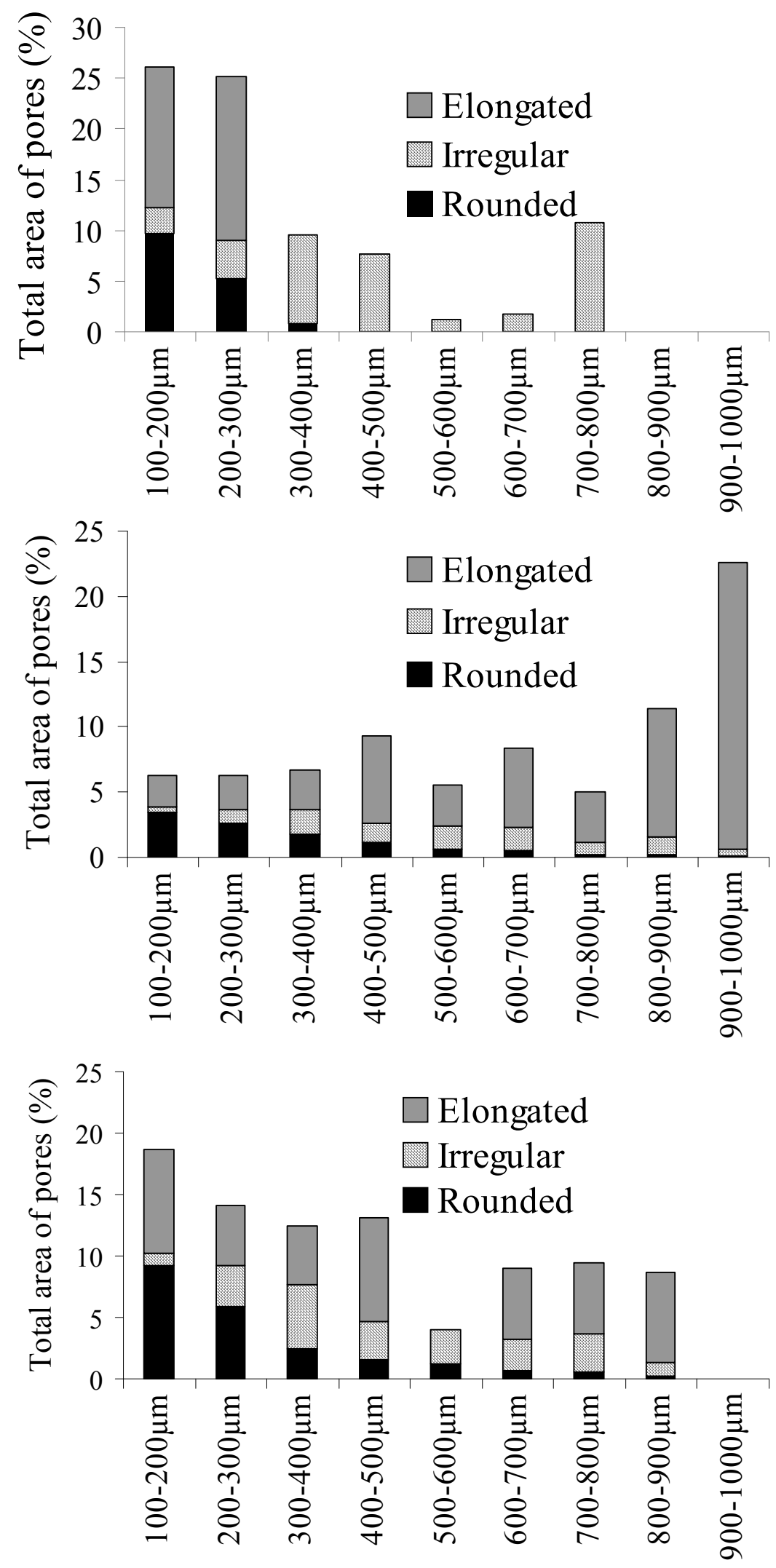
Figure 4

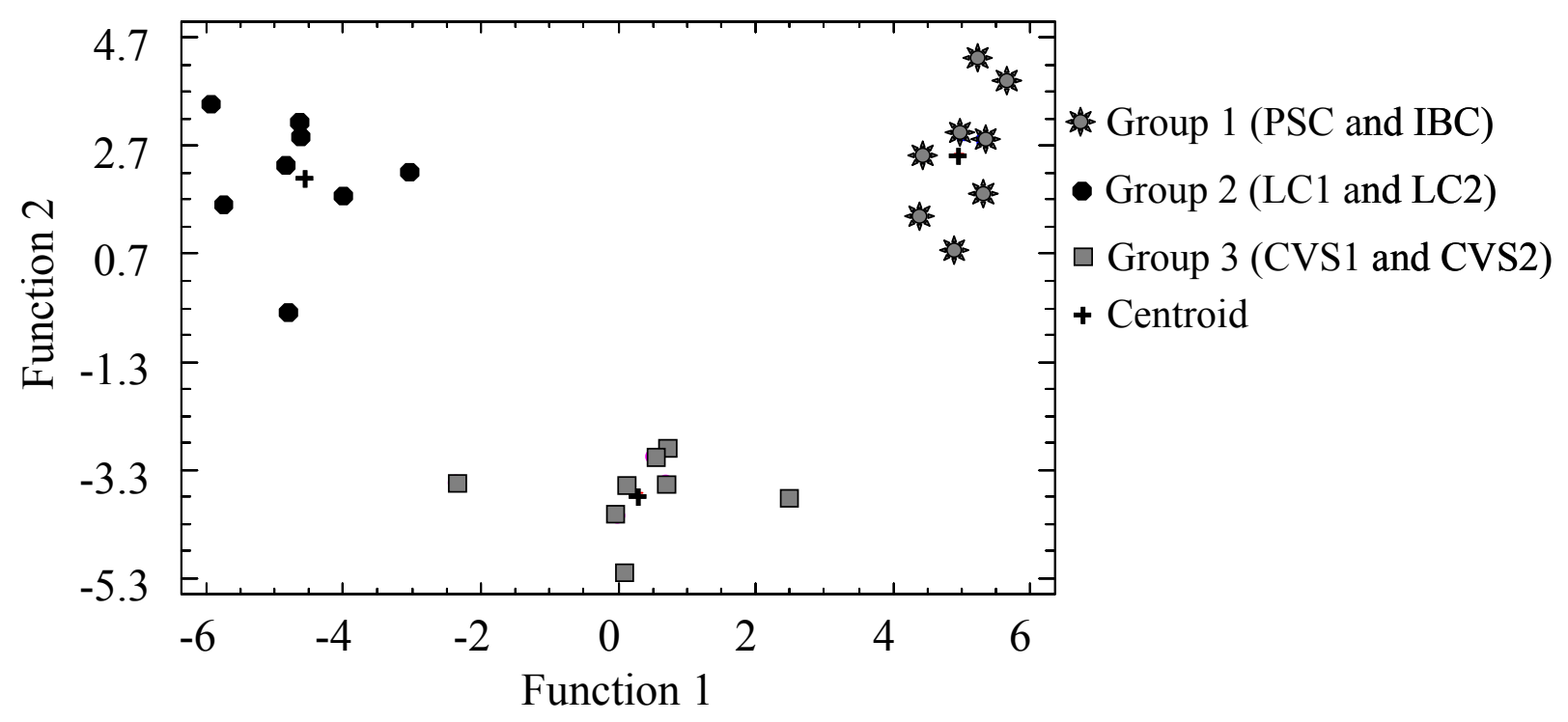


Table 1.- Mean and standard error values of physico-chemical soil parameters as indicators for every soil crust $\left({ }^{\dagger}\right)$, one way ANOVA ( $P$ significance) and LSD Fisher test (differences among soil crusts).

\begin{tabular}{|c|c|c|c|c|c|c|c|}
\hline \multirow[b]{2}{*}{ Indicators ${ }^{*}$} & \multirow[b]{2}{*}{$\boldsymbol{P}$} & \multicolumn{6}{|c|}{ Mean \pm standard error for each soil crust } \\
\hline & & PSC $^{\dagger}$ & IBC $^{\dagger}$ & $\mathbf{L C 1}^{\dagger}$ & $\mathrm{LC2}^{\dagger}$ & CVS1 $^{\dagger}$ & CVS2 $^{\dagger}$ \\
\hline Coarse sand $\left(\mathrm{g} \mathrm{kg}^{-1}\right)$ & 0.001 & $60.9 \pm 8.8 \mathrm{a}$ & $37.3 \pm 14.4 \mathrm{~b}$ & $16.2 \pm 6.4 \mathrm{c}$ & $21.0 \pm 9.5 \mathrm{bc}$ & $12.7 \pm 4.4 \mathrm{c}$ & $18.4 \pm 2.1 \mathrm{bc}$ \\
\hline Fine sand $\left(\mathrm{g} \mathrm{kg}^{-1}\right)$ & 0.184 & $199.0 \pm 21.0 \mathrm{a}$ & $190.6 \pm 38.5 \mathrm{a}$ & $198.7 \pm 16.1 \mathrm{a}$ & $341.9 \pm 150.2 \mathrm{a}$ & $301.5 \pm 21.3 \mathrm{a}$ & $242.6 \pm 33.3 \mathrm{a}$ \\
\hline Coarse silt $\left(\mathrm{g} \mathrm{kg}^{-1}\right)$ & 0.493 & $168.2 \pm 12 \mathrm{a}$ & $172.2 \pm 15 \mathrm{a}$ & $181.3 \pm 6.4 \mathrm{a}$ & $163.5 \pm 37.5 \mathrm{a}$ & $196.0 \pm 11.5 \mathrm{a}$ & $188.8 \pm 22.7 \mathrm{a}$ \\
\hline Fine silt $\left(\mathrm{g} \mathrm{kg}^{-1}\right)$ & 0.140 & $411.5 \pm 21 \mathrm{a}$ & $411.2 \pm 33.9 \mathrm{a}$ & $408.1 \pm 19.6 \mathrm{a}$ & $315.2 \pm 86.3 \mathrm{a}$ & $340.9 \pm 15.7 \mathrm{a}$ & $379.4 \pm 42.1 \mathrm{a}$ \\
\hline Clay $\left(\mathrm{g} \mathrm{kg}^{-1}\right)$ & 0.181 & $160.4 \pm 14 \mathrm{a}$ & $188.8 \pm 23.1 \mathrm{a}$ & $195.7 \pm 3.1 \mathrm{a}$ & $158.4 \pm 37.5 \mathrm{a}$ & $148.8 \pm 14.4 \mathrm{a}$ & $170.9 \pm 15.8 \mathrm{a}$ \\
\hline WC $(-33 \mathrm{kPa})$ & 0.184 & $22.2 \pm 1.9 \mathrm{a}$ & $25.9 \pm 2.1 \mathrm{a}$ & $26.4 \pm 0.5 \mathrm{a}$ & $27.0 \pm 5.7 \mathrm{a}$ & $30.5 \pm 2.1 \mathrm{a}$ & $26.1 \pm 1.9 \mathrm{a}$ \\
\hline WC $(-1500 \mathrm{kPa})$ & 0.159 & $10.9 \pm 1.3 \mathrm{a}$ & $8.5 \pm 0.6 \mathrm{a}$ & $7.9 \pm 1.2 \mathrm{a}$ & $7.8 \pm 2.4 \mathrm{a}$ & $7.0 \pm 0.6 \mathrm{a}$ & $8.3 \pm 0.7 \mathrm{a}$ \\
\hline TOC $\left(\mathrm{g} \mathrm{kg}^{-1}\right)$ & 0.000 & $9.5 \pm 4 \mathrm{bcd}$ & $7.1 \pm 0.8 \mathrm{~d}$ & $11.5 \pm 1.7 \mathrm{bc}$ & $12.9 \pm 1.8 \mathrm{~b}$ & $16.1 \pm 1.7 \mathrm{ab}$ & $19.0 \pm 1.6 \mathrm{a}$ \\
\hline $\mathrm{CaCO}_{3}\left(\mathrm{~g} \mathrm{~kg}^{-1}\right)$ & 0.025 & $242.7 \pm 22.1 \mathrm{a}$ & $213.3 \pm 17.5 \mathrm{a}$ & $232.0 \pm 14.3 \mathrm{a}$ & $164.9 \pm 23.2 b$ & $202.6 \pm 20.6 \mathrm{ab}$ & $223.4 \pm 19.4 \mathrm{a}$ \\
\hline Gypsum $\left(\mathrm{g} \mathrm{kg}^{-1}\right)$ & 0.000 & $243.5 \pm 41 \mathrm{a}$ & $105.6 \pm 14.1 b$ & $53.9 \pm 30.7 b c$ & $64.4 \pm 76.5 b c$ & $1.9 \pm 0.7 \mathrm{c}$ & $17.0 \pm 9 c$ \\
\hline $\mathrm{pH}$ & 0.849 & $7.6 \pm 0.9 \mathrm{a}$ & $7.6 \pm 0.1 \mathrm{a}$ & $7.6 \pm 0.2 \mathrm{a}$ & $7.8 \pm 0.1 \mathrm{a}$ & $7.7 \pm 0.1 \mathrm{a}$ & $7.7 \pm 0.4 \mathrm{a}$ \\
\hline $\mathrm{Ca}^{2+}\left(\mathrm{cmol} \mathrm{kg}^{-1}\right)$ & 0.062 & $0.61 \pm 0.1 \mathrm{ab}$ & $1.07 \pm 0.23 \mathrm{a}$ & $0.54 \pm 0.18 b$ & $0.52 \pm 0.28 b$ & $0.60 \pm 0.16 b$ & $0.27 \pm 0.03 b$ \\
\hline $\mathrm{Mg}^{2+}\left(\mathrm{cmol} \mathrm{kg}^{-1}\right)$ & 0.717 & $0.17 \pm 0.1 \mathrm{a}$ & $0.29 \pm 0.07 \mathrm{a}$ & $0.22 \pm 0.07 \mathrm{a}$ & $0.08 \pm 0.03 a$ & $0.61 \pm 0.6 \mathrm{a}$ & $0.09 \pm 0.02 \mathrm{a}$ \\
\hline $\mathrm{Na}^{+}\left(\mathrm{cmol} \mathrm{kg}^{-1}\right)$ & 0.038 & $0.09 \pm 0.01 \mathrm{a}$ & $0.08 \pm 0.04 \mathrm{ab}$ & $0.07 \pm 0.02 \mathrm{ab}$ & $0.03 \pm 0.01 b c$ & $0.05 \pm 0.02 b$ & $0.04 \pm 0.02 b$ \\
\hline $\mathrm{K}^{+}\left(\mathrm{cmol} \mathrm{kg}^{-1}\right)$ & 0.248 & $0.04 \pm 0.01 \mathrm{a}$ & $0.04 \pm 0.01 \mathrm{a}$ & $0.03 \pm 0.01 \mathrm{a}$ & $0.02 \pm 0.00 \mathrm{a}$ & $0.04 \pm 0.01 \mathrm{a}$ & $0.03 \pm 0.01 \mathrm{a}$ \\
\hline $\mathrm{SO}_{4}{ }^{2-}\left(\mathrm{cmol} \mathrm{kg}^{-1}\right)$ & 0.070 & $0.20 \pm 0.1 \mathrm{a}$ & $0.19 \pm 0.06 \mathrm{a}$ & $0.08 \pm 0.04 \mathrm{ab}$ & $0.05 \pm 0.05 \mathrm{~b}$ & $0.11 \pm 0.07 \mathrm{ab}$ & $0.05 \pm 0.01 \mathrm{~b}$ \\
\hline
\end{tabular}

'PSC: physical soil crust; IBC: incipient biological crust; LC: lichen crust; CVS: crusted vegetated surface.

${ }^{\ddagger}$ WC: water content $\left(\mathrm{kg} \mathrm{kg}^{-1}\right)$; TOC: total organic carbon; soil separates explained in the methods section.

Significant $(\mathrm{p}<0.05)$ differences after Fisher LSD are indicated by different letters within rows.

Table 2.- Mean and standard error values of the number of pores per $\mathrm{cm}^{2}$ (rounded, irregular and elongated), as indicators for every soil crust $(\dagger)$, one way ANOVA (P significance) and LSD Fisher test (differences among soil crusts).

\begin{tabular}{lrrrrrrr} 
& & \multicolumn{5}{c}{ Mean \pm standard error for each soil crust } \\
\cline { 3 - 8 } \multicolumn{1}{c}{ Indicators } & \multicolumn{1}{c}{$\boldsymbol{P}$} & \multicolumn{1}{c}{ PSC $^{\dagger}$} & \multicolumn{1}{c}{ IBC $^{\dagger}$} & \multicolumn{1}{c}{ LC1 $^{\dagger}$} & \multicolumn{1}{c}{ LC2 $^{\dagger}$} & CVS1 $^{\dagger}$ & CVS2 $^{\dagger}$ \\
\hline NP (all pores) & $\mathbf{0 . 0 3 7}$ & $133.3 \pm 7.1 \mathrm{~b}$ & $131.1 \pm 22.3 \mathrm{bc}$ & $291.4 \pm 82.3 \mathrm{ab}$ & $193.0 \pm 14.6 \mathrm{~b}$ & $367.1 \pm 76.4 \mathrm{a}$ & $232.4 \pm 93.2 \mathrm{abc}$ \\
NRP (all pores) & $\mathbf{0 . 0 2 7}$ & $90.0 \pm 3.5 \mathrm{bc}$ & $113.6 \pm 22.8 \mathrm{~b}$ & $235.4 \pm 116.3 \mathrm{ab}$ & $149.3 \pm 16.8 \mathrm{~b}$ & $304.4 \pm 116.0 \mathrm{a}$ & $186.7 \pm 69.7 \mathrm{abc}$ \\
NIP (all pores) & $\mathbf{0 . 0 8 9}$ & $37.1 \pm 2.9 \mathrm{ab}$ & $15.5 \pm 6.8 \mathrm{~b}$ & $49.3 \pm 23.9 \mathrm{a}$ & $34.9 \pm 6.6 \mathrm{ab}$ & $56.8 \pm 18.6 \mathrm{a}$ & $40.1 \pm 20.8 \mathrm{ab}$ \\
NEP (all pores) & 0.216 & $6.3 \pm 0.6 \mathrm{a}$ & $2.0 \pm 2.0 \mathrm{a}$ & $6.6 \pm 3.3 \mathrm{a}$ & $8.9 \pm 3.8 \mathrm{a}$ & $6.0 \pm 4.0 \mathrm{a}$ & $5.6 \pm 3.0 \mathrm{a}$ \\
NRP $(100-1000 \mu \mathrm{m})$ & $\mathbf{0 . 0 1 8}$ & $43.8 \pm 0.8 \mathrm{bc}$ & $73.8 \pm 17.6 \mathrm{~b}$ & $140.0 \pm 60.1 \mathrm{ab}$ & $88.0 \pm 10.6 \mathrm{~b}$ & $172.9 \pm 77.1 \mathrm{a}$ & $112.5 \pm 42.6 \mathrm{abc}$ \\
NIP $(100-1000 \mu \mathrm{m})$ & $\mathbf{0 . 0 8 1}$ & $33.8 \pm 0.8 \mathrm{ab}$ & $13.9 \pm 5.9 \mathrm{~b}$ & $44.4 \pm 23.8 \mathrm{a}$ & $31.4 \pm 8.9 \mathrm{ab}$ & $52.5 \pm 21.9 \mathrm{a}$ & $36.2 \pm 18.1 \mathrm{ab}$ \\
NEP $(100-1000 \mu \mathrm{m})$ & $\mathbf{0 . 0 3 6}$ & $2.9 \pm 0.3 \mathrm{~b}$ & $1.1 \pm 1.6 \mathrm{bc}$ & $5.1 \pm 2.7 \mathrm{ab}$ & $7.5 \pm 3.6 \mathrm{a}$ & $4.5 \pm 3.5 \mathrm{abc}$ & $4.6 \pm 1.5 \mathrm{ab}$ \\
NRP $(>1000 \mu \mathrm{m})$ & 0.668 & $0.0 \pm 0.0 \mathrm{a}$ & $0.0 \pm 0.0 \mathrm{a}$ & $0.2 \pm 0.4 \mathrm{a}$ & $0.1 \pm 0.2 \mathrm{a}$ & $0.3 \pm 0.6 \mathrm{a}$ & $0.3 \pm 0.2 \mathrm{a}$ \\
NIP $(>1000 \mu \mathrm{m})$ & 0.142 & $0.4 \pm 0.1 \mathrm{a}$ & $0.5 \pm 0.9 \mathrm{a}$ & $2.1 \pm 2.6 \mathrm{a}$ & $0.8 \pm 0.9 \mathrm{a}$ & $0.8 \pm 0.8 \mathrm{a}$ & $1.6 \pm 0.7 \mathrm{a}$ \\
NEP $(>1000 \mu \mathrm{m})$ & 0.561 & $0.0 \pm 0.0 \mathrm{a}$ & $0.0 \pm 0.0 \mathrm{a}$ & $0.1 \pm 0.2 \mathrm{a}$ & $0.0 \pm 0.0 \mathrm{a}$ & $0.0 \pm 0.0 \mathrm{a}$ & $0.0 \pm 0.0 \mathrm{a}$ \\
\hline
\end{tabular}

${ }^{\dagger}$ PSC: physical soil crust; IBC: incipient biological crust; LC: lichen crust, CVS: crusted vegetated surface.

${ }^{*}$ NP: total number of pores; NRP: number of rounded pores; NIP: number of irregular pores; NEP: number of elongated pores.

Significant $(p<0.05)$ differences after Fisher LSD are indicated by different letters within rows 
Table 3.- Mean and standard error values of 2D porosity (shape and size) as indicators for every soil crust $\left(^{\dagger}\right)$, one way ANOVA (P significance) and LSD Fisher test (differences among crusts).

\begin{tabular}{lccccccc} 
& & \multicolumn{5}{c|}{ Mean \pm standard error for each soil surface } \\
\cline { 3 - 8 } \multicolumn{1}{c}{ Indicators } & $\boldsymbol{P}$ & PSC $^{\dagger}$ & IBC $^{\dagger}$ & LC1 $^{\dagger}$ & LC2 $^{\dagger}$ & CVS1 $^{\dagger}$ & CVS2 $^{\dagger}$ \\
\hline AP (all pores) & $\mathbf{0 . 0 0 6}$ & $4.2 \pm 0.3 \mathrm{bd}$ & $3.5 \pm 1.0 \mathrm{bd}$ & $23.7 \pm 4.0 \mathrm{a}$ & $23.0 \pm 8.3 \mathrm{a}$ & $11.6 \pm 1.5 \mathrm{~b}$ & $13.2 \pm$ \\
& & & & & & $1.3 \mathrm{bc}$ \\
ARP (all pores) & $\mathbf{0 . 0 0 2}$ & $0.7 \pm 0.7 \mathrm{bcd}$ & $1.5 \pm 0.1 \mathrm{bc}$ & $3.0 \pm 0.9 \mathrm{ab}$ & $1.8 \pm 0.2 \mathrm{~b}$ & $3.2 \pm 0.9 \mathrm{a}$ & $0.9 \mathrm{abc}$ \\
AIP (all pores) & $\mathbf{0 . 0 0 6}$ & $1.7 \pm 0.1 \mathrm{~b}$ & $1.3 \pm 0.5 \mathrm{bc}$ & $4.5 \pm 1.7 \mathrm{a}$ & $3.5 \pm 1.2 \mathrm{ab}$ & $3.1 \pm 0.6 \mathrm{abc}$ & $5.0 \pm 1.3 \mathrm{a}$ \\
AEP (all pores) & $\mathbf{0 . 0 1 3}$ & $1.8 \pm 0.1 \mathrm{~b}$ & $0.7 \pm 0.7 \mathrm{~b}$ & $16.2 \pm 9.3 \mathrm{a}$ & $17.7 \pm 9.1 \mathrm{a}$ & $5.4 \pm 1.6 \mathrm{~b}$ & $5.9 \pm 2.0 \mathrm{~b}$ \\
ARP $\quad(100-1000$ & & & & & & & $2.1 \pm$ \\
$\mu \mathrm{m}) \quad$ & $\mathbf{0 . 0 0 4}$ & $0.5 \pm 0.1 \mathrm{bcd}$ & $1.4 \pm 0.4 \mathrm{bc}$ & $2.5 \pm 0.9 \mathrm{ab}$ & $1.6 \pm 0.3 \mathrm{~b}$ & $2.5 \pm 1.0 \mathrm{a}$ & $0.8 \mathrm{abc}$ \\
AIP $(100-1000 \mu \mathrm{m})$ & $\mathbf{0 . 0 1 8}$ & $1.6 \pm 0.2 \mathrm{~b}$ & $0.9 \pm 0.3 \mathrm{bc}$ & $2.6 \pm 0.9 \mathrm{a}$ & $2.0 \pm 0.6 \mathrm{ab}$ & $2.6 \pm 0.9 \mathrm{a}$ & $2.0 \pm 1.0 \mathrm{ab}$ \\
AEP $(100-1000 \mu \mathrm{m})$ & $\mathbf{0 . 0 0 9}$ & $1.4 \pm 0.2 \mathrm{cb}$ & $0.6 \pm 1.1 \mathrm{cb}$ & $14.1 \pm 10.9 \mathrm{ab}$ & $17.5 \pm 9.2 \mathrm{a}$ & $5.3 \pm 5.1 \mathrm{cb}$ & $5.9 \pm 2.0 \mathrm{~b}$ \\
ARP $(>1000 \mu \mathrm{m})$ & 0.637 & $0.0 \pm 0.0 \mathrm{a}$ & $0.0 \pm 0.0 \mathrm{a}$ & $0.2 \pm 0.4 \mathrm{a}$ & $0.1 \pm 0.1 \mathrm{a}$ & $0.3 \pm 0.5 \mathrm{a}$ & $0.3 \pm 0.2 \mathrm{a}$ \\
AIP $(>1000 \mu \mathrm{m})$ & $\mathbf{0 . 0 2 0}$ & $0.2 \pm 0.0 \mathrm{~b}$ & $0.3 \pm 0.4 \mathrm{~b}$ & $1.8 \pm 0.7 \mathrm{ab}$ & $1.5 \pm 1.2 \mathrm{ab}$ & $0.5 \pm 0.1 \mathrm{ab}$ & $3.0 \pm 1.4 \mathrm{a}$ \\
AEP $(>1000 \mu \mathrm{m})$ & 0.561 & $0.0 \pm 0.0 \mathrm{a}$ & $0.0 \pm 0.0 \mathrm{a}$ & $2.0 \pm 2.3 \mathrm{a}$ & $0.0 \pm 0.0 \mathrm{a}$ & $0.0 \pm 0.0 \mathrm{a}$ & $0.0 \pm 0.0 \mathrm{a}$ \\
\hline
\end{tabular}

TPSC: physical soil crust; IBC: incipient biological crust; LC: lichen crust; CVS: crusted vegetated surface. ¥AP: total area occupied by all pores (\%); ARP: area (\%) occupied by rounded pores; AIP: area (\%) occupied by irregular pores; AEP: area (\%) occupied by elongated pores.

Significant $(\mathrm{P}<0.05)$ differences after Fisher LSD are indicated by different letters within rows. 
Table 4.- Pearson's correlations between physico-chemical and porosity variables. Soil separates follow the French system.

\begin{tabular}{ccccccccc}
\hline & Crs sand & Crs silt & Total OC & $\mathrm{pH}$ & $\mathrm{Gypsum}$ & $\mathrm{K}^{+}$ & $\mathrm{Ca}^{2+}$ & $\mathrm{SO}_{4}^{2-}$ \\
\hline NP & -0.40 & 0.25 & $0.71^{*}$ & 0.20 & $-0.49^{*}$ & -0.11 & $-0.56^{*}$ & -0.34 \\
NRP & -0.42 & 0.27 & $0.70^{*}$ & 0.21 & $-0.51^{*}$ & -0.12 & $-0.53^{*}$ & -0.33 \\
NIP & -0.30 & 0.18 & $0.73^{*}$ & 0.13 & -0.40 & -0.04 & $-0.62^{*}$ & -0.37 \\
NEP & -0.22 & -0.07 & $0.70^{*}$ & 0.17 & -0.35 & -0.13 & $-0.72^{*}$ & -0.44 \\
NRP 100-1000 & -0.43 & 0.30 & $0.69^{*}$ & 0.18 & $-0.50^{*}$ & -0.16 & $-0.48^{*}$ & -0.30 \\
NRP > 1000 & -0.21 & 0.34 & $0.65^{*}$ & 0.08 & -0.40 & -0.10 & -0.36 & $-0.46^{*}$ \\
NIP 100-1000 & -0.30 & 0.18 & $0.73^{*}$ & 0.14 & -0.40 & -0.04 & $-0.63^{*}$ & -0.36 \\
NIP > 1000 & -0.32 & 0.18 & $0.64^{*}$ & 0.08 & -0.39 & -0.20 & -0.37 & -0.31 \\
NEP 100-1000 & -0.31 & -0.01 & $0.75^{*}$ & 0.16 & $-0.45^{*}$ & -0.16 & $-0.68^{*}$ & $-0.52^{*}$ \\
NEP > 1000 & -0.17 & -0.06 & -0.17 & $-0.65^{*}$ & 0.06 & -0.31 & -0.05 & -0.20 \\
AP & $-0.66^{*}$ & 0.27 & 0.17 & -0.10 & -0.23 & $-0.53^{*}$ & -0.16 & -0.42 \\
ARP & $-0.68^{*}$ & $0.50^{*}$ & $0.46^{*}$ & 0.31 & $-0.68^{*}$ & -0.08 & -0.12 & -0.19 \\
AIP & -0.42 & -0.11 & $0.64^{*}$ & 0.32 & $-0.57^{*}$ & -0.10 & $-0.63^{*}$ & $-0.50^{*}$ \\
AEP & $-0.55^{*}$ & 0.26 & 0.01 & -0.20 & -0.06 & $-0.55^{*}$ & -0.04 & -0.33 \\
ARP 100-1000 & $-0.73^{*}$ & $0.46^{*}$ & 0.41 & 0.28 & $-0.66^{*}$ & -0.15 & -0.07 & -0.08 \\
ARP >1000 & -0.13 & $0.44^{*}$ & 0.34 & 0.10 & -0.35 & 0.08 & -0.02 & -0.39 \\
AIP 100-1000 & $-0.51^{*}$ & 0.18 & 0.50 & 0.23 & $-0.52^{*}$ & 0.10 & $-0.52^{*}$ & -0.33 \\
AIP > 1000 & -0.27 & -0.24 & $0.56^{*}$ & 0.28 & $-0.45^{*}$ & -0.18 & $-0.53^{*}$ & $-0.46^{*}$ \\
AEP 100-1000 & $-0.57^{*}$ & 0.30 & 0.06 & -0.08 & -0.09 & $-0.53^{*}$ & -0.03 & -0.33 \\
AEP > 1000 & -0.17 & -0.06 & -0.17 & $-0.65^{*}$ & 0.06 & -0.31 & -0.05 & -0.20 \\
\hline
\end{tabular}

* significant at the 0.05 probability level; $\mathrm{NP}=$ total number of pores per $\mathrm{cm}^{2} ; \mathrm{NRP}=$ number of rounded pores; NIP = number of irregular pores; NEP = number of elongated pores; AP = area of all pores $(\%)$; ARP = area occupied by rounded pores (\%); AIP = area occupied by irregular pores (\%); $\mathrm{AEP}=$ area occupied by elongated pores $(\%)$. 
Table 5.- Infiltration coefficients and erosion rates for the six soil crusts under annual average conditions and under special rainfall events (event 1 : $\mathrm{P}=32 \mathrm{~mm}, \mathrm{I}=17 \mathrm{~mm} \mathrm{~h}^{-1}$, over dry soil; event $2: \mathrm{P}=22 \mathrm{~mm}, \mathrm{I}=52 \mathrm{~mm} \mathrm{~h}^{-1}$, over wet soil)

\begin{tabular}{ccccc}
\hline $\begin{array}{c}\text { Crust } \\
\text { type }\end{array}$ & $\begin{array}{c}\text { Annual Infiltration } \\
\text { Coefficient }(\%)^{\dagger \dagger}\end{array}$ & $\begin{array}{c}\text { Event 1 Infiltration } \\
\text { Coefficient }(\%)^{\ddagger}\end{array}$ & $\begin{array}{c}\text { Event 2 Infiltration } \\
\text { Coefficient }(\%)^{\ddagger}\end{array}$ & $\begin{array}{c}\text { Sediment } \\
\text { yield }\left(\mathrm{g} \mathrm{m}^{-2}\right)\end{array}$ \\
\hline PSC & $65.6 \pm 0.9$ & $47.3 \pm 5.2$ & $50.1 \pm 4.5$ & $203.5 \pm 26.1$ \\
IBC & $71.7 \pm 6.2$ & $61.5 \pm 5.6$ & $54.4 \pm 0.5$ & $80.9 \pm 26.5$ \\
LC1 & $63.3 \pm 0.5$ & $57.0 \pm 4.3$ & $46.5 \pm 7.8$ & $23.5 \pm 8.7$ \\
LC2 & $74.6 \pm 3.0$ & $81.8 \pm 3.9$ & $77.1 \pm 0.1$ & $7.0 \pm 0.2$ \\
CSV1 & $78.0 \pm 3.9$ & $86.3 \pm 0.8$ & $81.0 \pm 11.5$ & $1.0 \pm 1.0$ \\
CSV2 & $73.9 \pm$ n.a. & $85.0 \pm 0.7$ & $75.1 \pm 2.9$ & $1.4 \pm$ n.a.
\end{tabular}

${ }^{\dagger}$ These values correspond to the annual mean values of 3 years of monitoring on $0.24 \mathrm{~m}^{2}$ plots ( 3 replicates on all surface crusts except CSV2 which had 2).

* Infiltration coefficient $=$ ratio between annual infiltration rate $(\mathrm{mm})$ and annual rainfall $(\mathrm{mm})$.

n.a. $=$ not available. 